\title{
活動等高線についての基礎研究 $-R^{*}$ (Ridge) の 3 次元化 への拡張とその応用手法について一
}

その 1 論理設定段階

$$
\text { 正会員芦 川 智水 }
$$

\section{1. 序}

建築あるい都市にお沙る多様な現象を内包する場を 〈現象空間〉とし，現象空間に内包される現象の要素を 記述する場合〈位置を保存する図〉を用いる事が行なわ れる。その代表例が地図である。活動等高線論 (AC 論) は，この位置を保存する図への図像表現に関する方法的 提案をする事を目的とする。この目的に至る為に $\mathrm{AC}$ 論 の課題は，次の 4 つに区分される。

(1) AC 論の手法としての性能と構造の問題

(2) 対象としての現象空間加ら現象要素抽出の問題

(3) $\mathrm{AC}$ 論による現象空間の記述と把握の問題

(4) AC 諭による論理化の問題

$\mathrm{AC}$ 論の出発点は, 前記 4 つの課題のうち第 1 の手法 としての性能と構造の問題として始められた。すなわ ち，表現された幾何学的な図形に対する言語の開発を第 1 のステップとした。

$\mathrm{AC}$ 論の表現手法の中心は等高線図である。この等高 線図により表現する為の対象の形態は曲面と考元られ る注1)。こ狆を，位置を保存する図の上で考えるなら， 任裹の位置に対して，その位置の活動状況を量として示 す事を基本に㧊いている。もちろん，等高線地形図もそ のらちの 1 つの例と考えられよう。この様な観点加ら出 発して, 表現媒体の最も単純な形態としての単一閉曲線 図を第 1 の対象とし，その構造概念として単一閉曲線図 の $R^{*}$ (Ridge) を抽出した。単一閉曲線図形の $R^{*}$ (Ridge）の抽出と定義とその性状記述を中心とする基礎的概 念設定に関しては，活動等高線（AC）に関寸る基礎研 究一その 1 閉曲線図形におりる構造概念の確立一(藤井 明, 日本建築学会論文報告集第 267 号 (1978))，に示さ れている。これに対して; 当論文は，単一閉曲線の $R^{*}$ といら 2 次元平面の事象を出発点として, 一般の等高線 図に示される如くの 3 次元空間への論理㕬張の糸口をつ かむ事を目的としたものである。今回は，単一閉曲線図 形の $R^{*}$ から誘導される標準形の概念をもとに，3 次元 への拢張を試みるものである。標準形と一般等高線の対

* 東京大学 助手

(昭和 53 年 5 月 17 日本稿受理・討論期限昭和 54 年 12 月末日)
照において，流線を利用するまでの論理設定段階をその 1 に示し，流線による $R^{*}$ の 3 次元化の手法を集落の全 体配置に適用し，パターン分析を通じて，その手法の有 効性を論ずる段階をその 2 に示してある。

\section{2. 前 提}

$R^{*}$ (Ridge) は，図形（単一閉曲線として示される平 面図形）の中心概念を，重心等の点的な中心加ら，線的 な中心几転換し, より良い図形の構造的な把握を可能に する為の媒体として，考完られたものである。その定義 を示すと，以下の如くになる。

$R^{*}$ の定義 : 「平面上の閉曲線 $C$ の内部領域，外部領 域に対する平衡発展により得られる平行閉曲線群を

$$
\left\{C^{\prime}[i]\right\},\left\{C^{\prime}[e]\right\}
$$

とするときこの平行閉曲線群の特異点の軌跡を閉曲線 $C$ の* といら」

この閉曲線図形の $R^{*}$ は, 平面に括ける閉曲線図形と, 1 対 1 対応が可能である事が示されている。また， $R^{*}$ は 図形の内接円の中心の軌跡である事も示されている注2)。 閉曲線図形と，閉曲線図形の $R^{*}$ を定義する為に用意し た平行閉曲線群とを，合わせ考えた時に，標準形の概念 が生ま机る。もともと，標準形とは，等高線図形の部分 としての単一閉曲線が与えられた時, その図形をもと に, 他の部分の閉曲線群を予測し, 最む標準的な全体と しての姿を想定したものである。 $R^{*}$ を媒介として，閉 曲線図形に対応する標準形とは，次の様に考えられる。

「標準形とは，閉曲線に対して，平衡発展として考え られる平行閉曲線群を，そのまま等高線とみなす事によ り想定される立体図形である」

これは, 図に示される如く, 点 $P(x, y)$ の標高 $H$ が, 点 $P$ から閉曲線への最短距離を $L(x, y)$ とした時に，

$$
H(x, y)=k \times m \times L(x, y)+H_{0} .
$$

ただし $H_{0}$ : 基盤の高さ $m:$ 点 $P$ が, 閉曲線の内部領域の場合 +1 , 外部領城の場合 -1

$$
k: \text { 定数 }
$$

で示されるものである。

この標準形は, 閉曲線の形態に即した自然の立体化の 


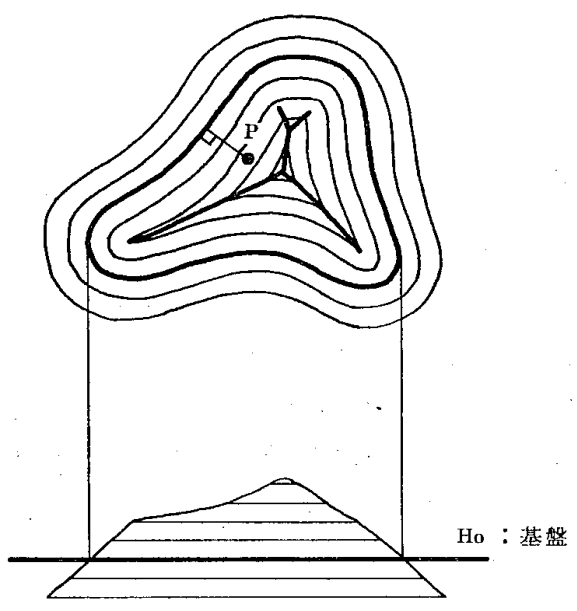

図-1

手法として, 次の様に考えて形成される立体としても考 えられる。まず，与えられた閉曲線に対して，その形に 切り抜加れた板を考光，次に，その板に対して，上から 砂を落としてゆく。砂は板上に積るが，ある勾配以上に なると砂は板からこぼれ落ちる。板の上全体にまんべん なく砂を積んでゆくと，もうこれ以上砂を積む事ができ ない状態で達する。この様にして形成される立体は, 板 の形態に準拠したある種の定常状態を示している。

この立体について考えてみると，その決定因は，板の 形と砂の安定勾配の 2 つである。砂の安定勾配の上限を $\theta$, 板の周縁部 $C$ から $\Delta H$ の高さの点を $p$ (点 $p$ の板 上の投象を $\left.p^{\prime}\right)$ とするとき，点 $p$ に落下した砂は，周 縁部 $C$ 上の点 $q$ に向って転がり落ちるが，その経路は， 点 $p$ から周縁部 $C$ 一の最急勾配路に従ら。したがって，

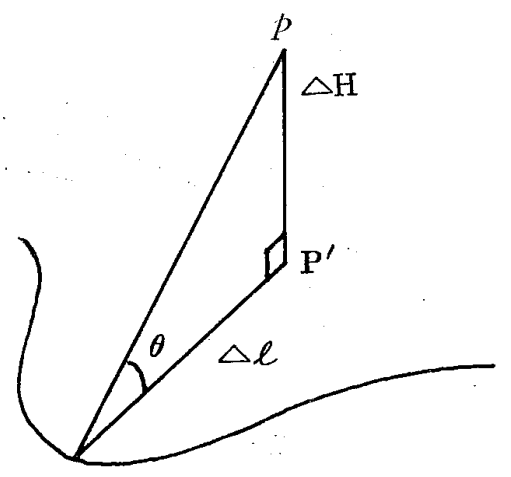

図-2

$$
\Delta l=d\left(p^{\prime}, q\right)
$$

とすると

$$
d\left(p^{\prime}, q\right)=d\left(p^{\prime}, C\right)(=\Delta l)
$$

となっている。つまり, 点 $p^{\prime}$ は周縁部 $C$ に対して, 距 離 $\Delta l$ の点になっているが， $\Delta H$ の高さにある点全てに ついて考えると，高さ $\Delta H$ にある点の等高線は，周縁 部 $C$ に対する距離 $\Delta l$ の平行閉曲線となり,

$$
\Delta H=\tan \theta \cdot \Delta l
$$

の関係が成立しており, 前述の標淮形との対応が認めら れよう。

\section{3. 論理設定過程}

閉曲線に対応する標準形の概念と，流線といら地形構 造把握手法を用いて，一般等高線図（多重閉曲線図）の 構造的把握へせまる一つの道筋が以下に示される。

(1) 等高線図は, 平面上の点 $(x, y)$ の標高を $H$ と した時, $H=f(x, y)$ なる標高函数 $f\left(R^{2} \stackrel{f}{\rightarrow} R\right)$ により, 2 次元平面 $R^{2}$ ，標高を示す実数の集合 $R$ 亿写像す るものである。この標高平面図において，場所に対する 一価性と，場所に対する連続性を前提とする。

（2）一般に，等高線図として示されるものは，広が りを有する人間活動の場から，ある目的事象に対応した 領域を切り取った形で示される場合が多い。すなわち， 切り取る為の画面の設定が, 重要な要素となる。画面は 矩形であったり，行政区域境界といら不整形な画面であ ったりする。この際に問題となるものが，境界条件の設 定である。当論理の設定条件として，この画面の境界条 件設定に対する制約を除外する事とする。標高函数を， $H=f(x, y)$ ，画面領域を $G$ とし，基盤高さ $H_{0}$ を設定 した時に

$$
D=\left\{(x, y) \mid(x, y) \in R^{2}, H=f(x, y), H \geqq H_{0}\right\}
$$

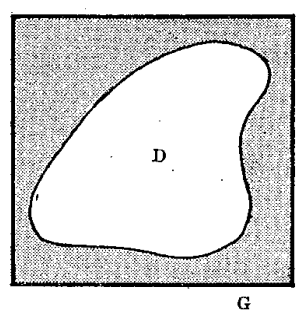

斜線部分㛈若雭加与 除加部分と在る

図一3

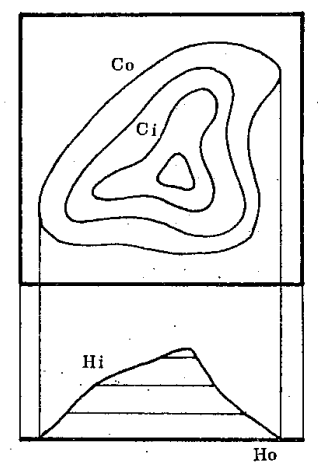

図-4
なる領域 $D$ が， $D \subset G$ なる限定条件を付加する事によ りこの制約を排除する事ができる。等高線図は，標高函 数に掠いて, $H \geqq H_{0}$ なる領域 $D$ を対象領域とし， $D$ 内に描加れる等高線，すなわち

$$
\begin{aligned}
C_{i}=\{(x, y) \mid(x, y) & \in R^{2}, f(x, y)=H_{i}, \\
H_{i} & \left.=H_{0}+\Delta H \times i, i=0, n\right\}
\end{aligned}
$$

なる多重閉曲線群として示されるものである。

（3）流線の定義：対象領域 $D$ 内の任意の点 $P(x, y)$ を与えた場合，曲面がなめらかであるならば， $\partial z / \partial x$ ， $\partial z / \partial y$ が定まり，最急勾配路が決定される。この時， $P$ から $\Delta R$ の距離への最急勾配路に沿った移動点 $P^{\prime}\left(x^{\prime}\right.$, $\left.y^{\prime}\right)$ が定まる。 $P^{\prime}\left(x^{\prime}, y^{\prime}\right)$ は以下の条件で決定される。

i.) $\partial z / \partial x=0, \partial z / \partial y=0$ の場合, 曲面は, $P$ に掠 いて水平となり, 最急勾配路の端点となるか, あ るいは，最急勾配路が無いかのいずれかである。

ii) $\partial z / \partial x=0, \partial z / \partial y \neq 0$ の場合

(1) $\partial z / \partial y>0$ の時 
$x^{\prime}=x, y^{\prime}=y \pm \Delta R$ (符号は上り，下りを示す）

(9) $\partial z / \partial y<0$ の時

$x^{\prime}=x, y^{\prime}=y \mp \Delta R$

iii） i), ii）以外の場合

(1) $\partial z / \partial x>0$ の時

$x^{\prime}=x \pm \Delta R / \sqrt{1+\{(\partial z / \partial y) /(\partial z / \partial x)\}^{2}}$

$y^{\prime}=y \pm \Delta R \cdot(\partial z / \partial y) /(\partial z / \partial y) /$

$$
\sqrt{1+\{(\partial z / \partial y) /(\partial z / \partial x)\}^{2}}
$$

(D) $\partial z / \partial x<0$ の場合

$x^{\prime}=x \mp \Delta R / \sqrt{1+\{(\partial z / \partial y) /(\partial z / \partial x)\}^{2}}$

$y^{\prime}=y \mp \Delta R /(\partial z / \partial y) /(\partial z / \partial x) /$

$$
\sqrt{1+\{(\partial z / \partial y) /(\partial z / \partial x)\}^{2}}
$$

上記の如く，隣接点相互の関係が設定された時に，最 急勾配路をたどって流線を描く事が可能となる。

任意の点 $P$ を通る流線とは， $P$ を起点として, 最急 勾配路をたどって上り，あるいは下り，端点に至る曲線 である。ただし，端点とは，勾配の変換点（水平点を含 む）あるいは基盤高さの点のいずれかである。一般的に 流線は，2 つの端点を有する弧状曲線として描く事がで きる。

(4) $R^{f}$ の導入: 今, 領域 $D$ の内部を対象とし, $C_{0}$ (領域 $D$ の境界) 上の点を $P$ とし, $P$ を起点とし て, 最急勾配をたどる流線を描く。この時に，(3) で設 定した最急勾配の設定が出来ない場合がある。つまり

i ）曲面が水平の場合

ii）接平面が一意に定まらない場合

である。流線は，起点を出発して登ってゆくが，最急勾 配が下る点，すなわち頂点に至った時を流線の端点と考 えれば，i）の場合もこの端点に含める事ができよう。 この場合, 端点と上り勾配に括ける端点となりらる点 は, 曲面の頂点 (極大点), 変曲点, 水平点のいずれか と考えられる。ii）の場合は，図の如く，2 種微倸数を 有する曲面が接する点（2 以上の微保数を有する事も考 えられる) である。この場合，次の操作により，流線の 一意性が確保できる。すなわち， $P_{1}$ に批ける 2 種類の 接平面に関して，最急勾配点を(3) により算定し， そ の異なる 2 点の $x y$ 平面への射影が

a） 2 種類の接平面の交わりとして形成される直線の

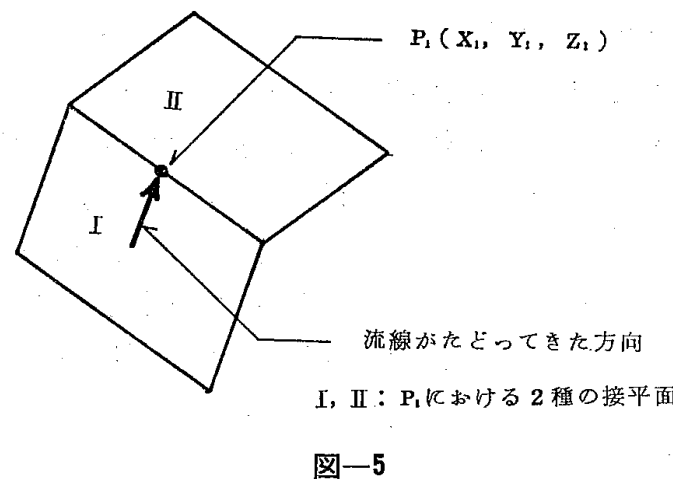

$x y$ 平面への射影により相異なる領域に区分けされ る場合は， $P_{1}$ より接平面の交線を上へたどる方向 をとり

b）上記交線に関して，2 点が同一領域に存在する場 合は，流線がたどってきた側の接平面Ｉに対する接 平面圥りり算定された最急勾配の方向をとる。

a）の場合法，図一6 に示される如く，稜線を形成して いる場合であり，b）の場合は，斜面にエッジが作られ ている場合である。標高函数の一価性と連続性の条件 に，なめら加さ(微分係数の連続性) の条件を付加する なら，この様な状況は生起しない。

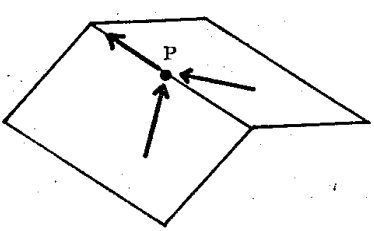

a) の場合（䆌源）

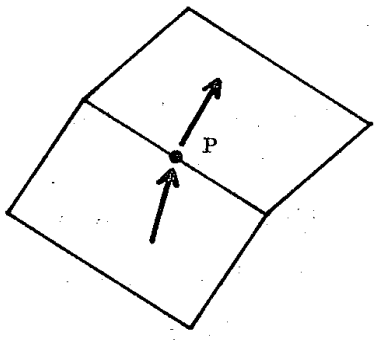

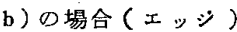

図一6

さて，以上の様にして描かれる流線は，一般的な形と して一方の端点に $C_{0}$ ( $D$ の境界となる閉曲線).上の点 を, 一方の端点として頂点（極大点）あるいは変曲点， 水平点をとっている。今， $C_{0}$ の任裏の 2 点 $P_{1}, P_{2}$ ，を起 点として流線を描いた時, 両者の端点（上り勾配に捛け る端点）としての頂点 $P_{t}$ を共有し，しかも $P_{t}$ 一至る 手前 $P_{r}$ 汃ら流線を共有していたとする（図一7 参照）。

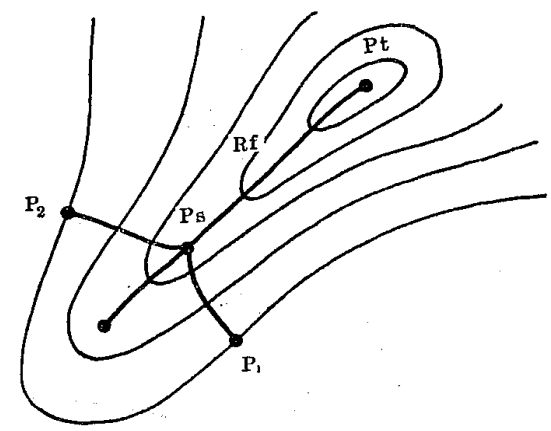

図-7

$C_{0}$ で囲をれた領域 $D$ を， $P_{1} P_{r} P_{2}$ により区分された領 域で, $P_{t}$ を含まない部分を $\bar{D}_{i}$ とする。 $\bar{D}_{i}$ に, 流線 の端点となる要素が無かった場合， $\bar{D}_{i}$ 内の任意の点を 起点とした流線は，すべて $P_{r} P_{t}$ を共有し， $P_{t}$ を端点 とする。なぜなら，流線相互は交差する事はないからで ある(もし交差したとすると，その交差点に押いて 2 種 類の最急勾配路がとれ，最急勾配路の一意性に反するか らである)。以上の様に， $\bar{D}_{i}$ 内の点を起点とする流線 を，お抢む称描くと図一8 の如くになり，流線相互の共 有部分が明確となる。図に上れば，流線は，他の流線と 共有する部分と，共有しない部分に区分できる事がわか 


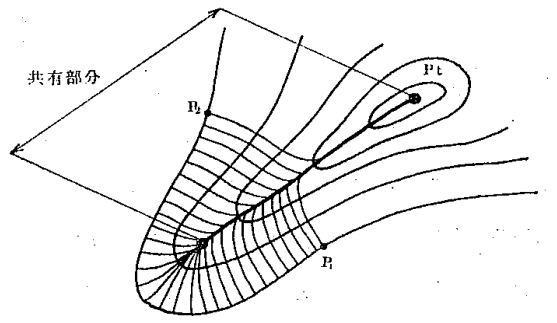

図-8

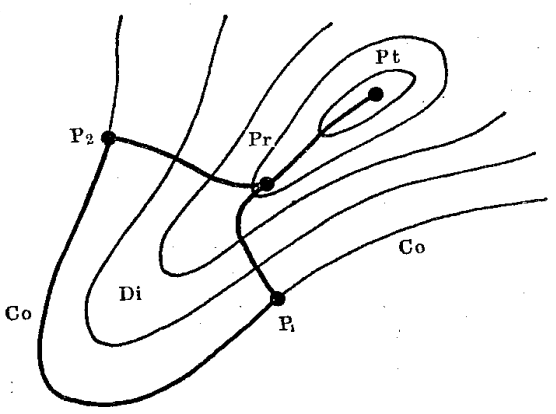

图-9

る。図一9 の流線共有部分の任意の点 $P_{s}$ を設定した場 合, この点に至る流線で, $P_{s} P_{t}$ のみを流線の共有部分 とする流線が，少なくとも本設定可能であ る事がわかる(図一9 で, 流線 $P_{1} P_{s} P_{t}$, $P_{2} P_{s} P_{t}$ で, $P_{s} P_{t}$ を共有部分とし, $P_{1} P_{s}$, $P_{2} P_{s}$ は共有部分をむたない)。最急勾配を たどる線である事から，これらの対応関係 を示す線としての流線は，相互に交差しな い事が容易に示せる。

今，この流線相互の共有関係を有する点 の集合で, しかも, 流線相互の対応関係を 示す点としての集合を，仮に $R^{f}$ としてお き，今後の略記号として使用する事とす る。

（5）標準形の再考：さて, 単一閉曲線 図形の構造概念として $R *$ (Ridge) を導入 し， $R^{*}$ を媒介として，立体としての標準 形が誘導された事は，すでに示されてい る。 $R^{*}$ を媒介とした標準形と， $R^{f}$ との 関係安把握し，一般等高線図（多重閉曲線 群）構造概念抽出への道筋をたどる前提と して, 標淮形の構造を把握しておく必要が ある。

（a）単一閉曲線図形の中心構造：単一

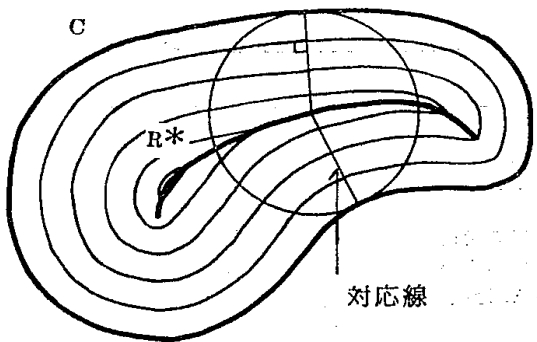

図-10
閉曲線図を出発点に置き, 線的な構造を示すむのと して $R^{*}$ を抽出した。これは，単一閉曲線図形に対 寸る平行閉曲線により定義ゔりら机， $R *$ の存在性 と，一董性が示されている。

(b) 単一閉曲線図形に 1 対 1 亿対応する構造として

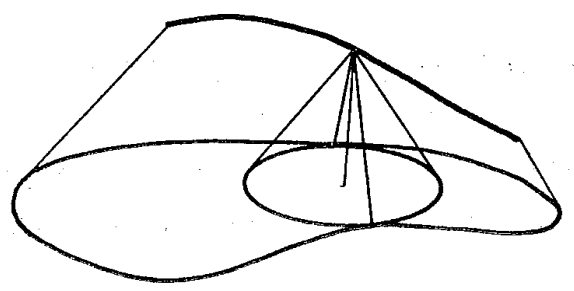

図-11
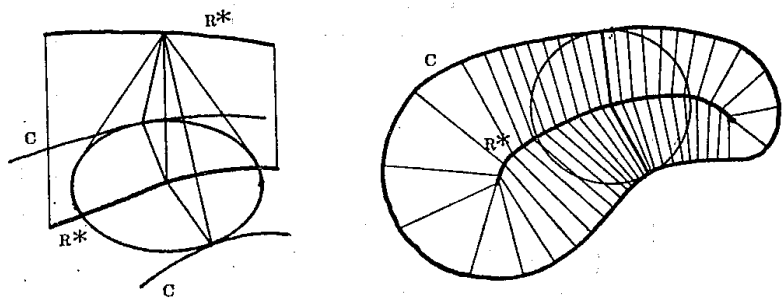

図-12

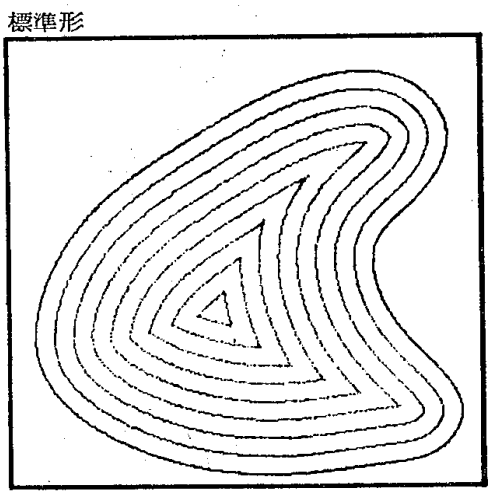

対応線民 $R^{*}$
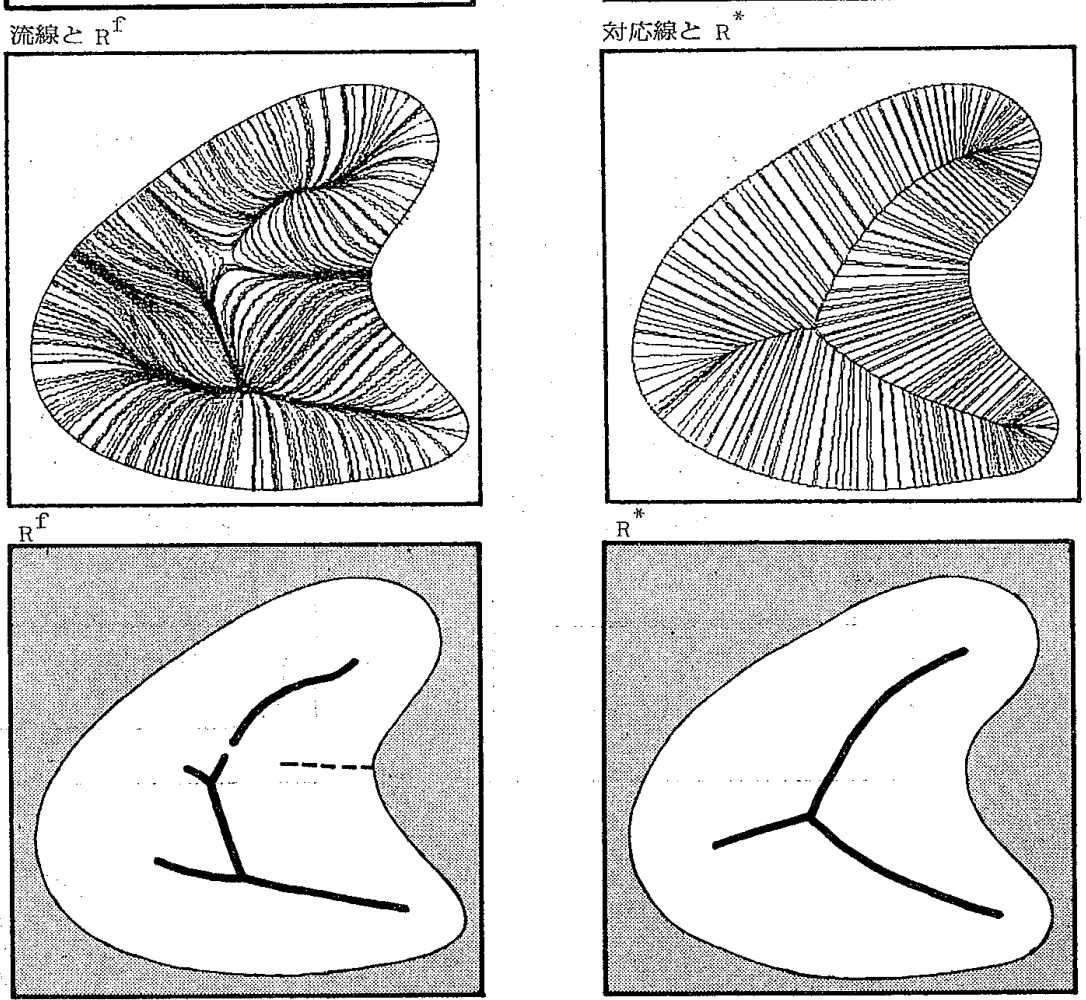
示される $R^{*}$ は，上記図形に対寸る内接円の中心の 軌跡として示される。この内接円の接点と中心を結 ぶ線が， $R^{*}$ と閉曲線図形との対応関係を示寸もの となり，この線分は，円接円の半径である為，対态 線の長さは等しく，また，平行閉曲線と常に垂直に 交差している。

（c）平行閉曲線を，与条件としての単一閉曲線を基 盤においた時の等高線として見るならば，一つの立 体図形として示せる。この立体を単一閉曲線図形に 対する標準形と呼ぶ。この標準形は，別な観点から
考えると，単一閉曲線に対応寸る板の上に，可能な 限りの理想砂を乗せた時に生ずる形態に対応づけら れる。標準形の特徵的な性質は，斜面が等勾配で構 成されている事である(図一11)。

(d) 平面図形に打ける内接円は，標準形に打いて は, 円錐形と見る事ができ，頂点は $R^{*}$ に対応し， $R^{*}$ と，基盤となる単一閉曲線との対応線は，円錐 斜面の稜に対応し，等勾配斜面の最急勾配に対応し ている(図一12)。

(6) $R^{f}$ と標淮形

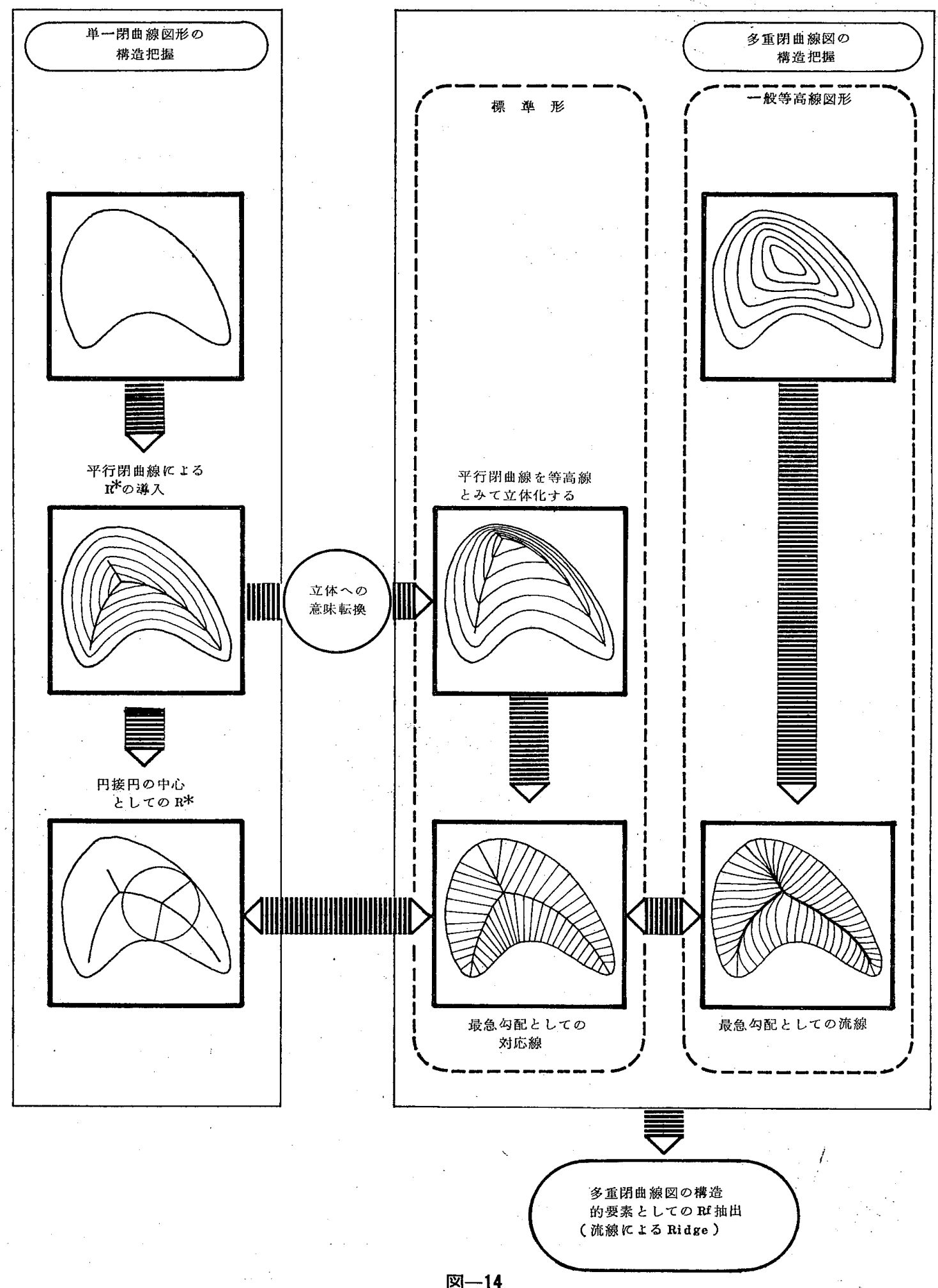


一般の等高線図（多重閉曲線図）の構造を示婹要之 して $R^{f}$ を定義づける為には， $R^{f}$ と標準形の $R^{*}$ との 関係を把握しなければならない。

（a）今，基盤 $D$ を統一した 2 種類の等高線図を考え る。Aの等高線図は, 基盤閉曲線 $C_{0}$ に対する平行 閉曲線で構成されており，基盤に対する標蕉形とし て示されている。これに対して，Bの等高線図は任 意性を有した，多重閉曲線図形として示される。

(b) $\mathrm{A}$ 標準形に対しては，基盤の閉曲線図 $R^{*}$ と との対応関係它示す線を描き， $\mathrm{B}$ に対しては， $R^{f}$ を描く。この際の, 対応線と, 流線注, 共に, 立体 の斜面の最急勾配をたどる線に対応している。ま た，基盤としての閉曲線と，立体の稜線の対応関係 を示しているといら点でも共通の性質を有する事が 認識されよう。

(c) $R^{*}$ と $R^{f}$ の 2 種類の概念を, もとの等高線に もどして考えてみると次の事が言える。2 種類の等 高線を地形に見立てると，この地形に流下する雨水 の流れが，R*，R $R^{f}$ にり区分される事になり，R*， $R^{f}$ は，地形における「分水界」の性質䘮有してい る事が示せる（図一13）。

（7）一般等高線図（多重閉曲線図）に招ける構造概 念としての $R^{f}$ (流線による Ridge)

単一閉曲線図の構造概念として $R^{*}($ Ridge ) を導入し, 一般等高線図形（多重閉曲線図）の構造概念一の㹡張党 訣る為に， $R^{f}$ を考えてきたが，標準形の性状を媒介に $R^{f}$ の概念把握がなされ， $R *$ との関係が明確にされた。 また $R^{f}, R^{*}$ ともに，地形概念としての分水界との対応 づけが可能である事も示されてきたわけである。
以上の過程を孔とに，一般等高線図（多重閉曲線図） の構造要素として，Rf 考考察の対象しする事ができる。 $R^{f}$ は, 標準形の $R^{*}$ 孛媒介にして導入された構造要素 である。単一閉曲線の $R *$ * は，あくをでも平面図形の構 造を示すものであり, 立体図形としての一般等高線の構 造とは，基本的に相違するものである。 $R^{f}$ が，一般等 高線図に於いて，その構造概念としての有効性をもつか 否が， $R^{f}$ によって，一般等高線図がどのように記述 され，その構造が表現できるか否かにかかっているとい える。この論は,一つの抽出された要素の有効性を問 所に，その主旨があるといえる。

4. ま と

$R^{f}$ の抽出過程を, その論理を追って示すと, 図一14 に示す如くのフローに表現できる。

注 1) 位置を保存する図上に打ける活動状況を把握する場 合, 観測の問題と, 観测により得られた测定值をもとに, 等高線図化すなわち曲面化する問題の 2 つの課題があ る。そして, 観測の方法として, 位置を保存する図上に 格子組みを設定し, その格子点上の测定值を求める事が よく行なわれる。この格子売上の測定值をもとに曲面化 を近似的に行なら方法として，3次の近似曲面による曲 面化が現段階では最良の方法と若える。それは，求めら れた曲面がなめらかな連続曲面 (微分可能でしかも, 微 分傾数の連続性を保証する連続曲面）として示されるか らである。これに対して，曲面自体がすでに存在する場 合, 例えば地形図の如くの時には, その曲面の形態を数 量的に把握する手法が考えられねばならない。例えば， 自動読み取り手法の如くである。そして，この場合，一 般的には曲面が, ほとんど至る所で微分可能 (微分不可 能な点が，点あるい線として存在する）の性状一と拡 張されなければならないであるう。

注 2) 藤非 明, 活動等高線 (AC) に関与る研究一その 1 , 閉曲線図形における棈造概念の確立一（日本建築学会論 文報告集第 267 号，1978）参照。

\section{S Y N O PS I S}

U.D.C. 72.013

\section{FUNDAMENTAL STUDY OF ACTIVITY CONTOUR -THE EXTENSION TO THREE DIMENSIONAL SPACE OF $R^{*}$ (RIDGE) AND APPLICATION METHOD--}

Part 1 Logical structure

by SATORU ASHIKAWA, Assistant of Tokyo Univ., Member of A.I.J.

This paper is depend upon the fundamental study of "Activity Contour". In this report, " $R$ " is defined from the viewpoint of the quality of water flowing on the curved surface of activity contour.

" $R$ " is the structural concept of ordinary contour surface. The concept of " $R$ " $f$ " is stand on the concept of " $R$ " " (Ridge) which is the structural concept of closed curve.

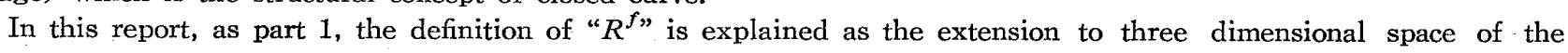
concept of “ $R^{*}$ ". 